\title{
Effects of high carbohydrate or high protein energy-restricted diets combined with resistance- exercise on weight loss and markers of health in women with serum triglyceride levels above or below median values
}

\author{
Jonathan M Oliver ${ }^{1 *}$, Julie Y Kresta ${ }^{1}$, Mike Byrd ${ }^{1}$, Claire Canon ${ }^{1}$, Michelle Mardock${ }^{1}$, Sunday Simbo ${ }^{1}$, Peter Jung ${ }^{1}$,

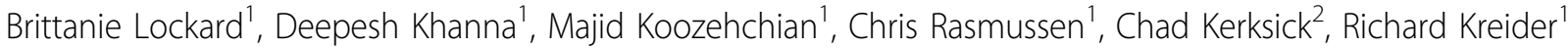

From International Society of Sports Nutrition; 7th Annual ISSN Conference and Expo

Clearwater Beach, FL, USA. 24-26 June 2010

\section{Background}

A diet high in protein has been shown to have beneficial effects on weight loss and triglyceride (TG) levels when combined with exercise. Recent research has also shown that a diet high in protein in the absence of exercise promotes more favorable results for individuals above the median TG (mTG) levels $(>133 \mathrm{mg} / \mathrm{dL})$. The purpose of this study was to determine if women with TG above median values experience greater benefits to a diet and circuit resistance-training program.

\begin{abstract}
Methods
442 apparently healthy sedentary obese women $(48 \pm 12$ yrs, $64 \pm 3$ in, $201 \pm 39 \mathrm{lbs}, 45 \pm 5 \%$ fat) completed a 10 -wk exercise and diet program. All subjects participated in Curves circuit training (30-minute hydraulic resistance exercise interspersed with recovery floor calisthenics performed at 30-seconed intervals 3 days/wk) and weight loss program $(1,200 \mathrm{kcal} / \mathrm{d}$ for $1 \mathrm{wk} ; 1,600 \mathrm{kcal} / \mathrm{d}$ for 9 wks). Subjects were randomly assigned to a high protein or high carbohydrate isocaloric diet. The high protein (HP) group $(\mathrm{n}=200)$ consumed $30 \%$ fat, $55-63 \%$ protein, and $9-15 \%$ carbohydrate diet while the high carbohydrate $(\mathrm{HC})$ group $(\mathrm{n}=242)$ consumed $30 \%$ fat, $55 \%$ carbohydrate, and $15 \%$ protein diet. Pre and post measurements included standard anthropometric
\end{abstract}

${ }^{1}$ Exercise and Sports Nutrition Laboratory, Texas A \& M University, College Station, TX, USA

Full list of author information is available at the end of the article measurements including dual energy X-ray absorptiometry (DEXA), as well as resting energy expenditure (REE), metabolic blood analysis, and blood pressure. Subjects were stratified into a lower or higher TG group based on the $\mathrm{mTG}$ value observed $(125 \mathrm{mg} / \mathrm{dL})$. Data were analyzed by MANOVA with repeated measures and are presented as means \pm SD percent changes from baseline.

\section{Results}

Fasting serum TG levels differed between groups stratified based on mTG levels ( $<$ mTG $86 \pm 24$ vs $>$ mTG 204 $\pm 84 \mathrm{mg} / \mathrm{dL}, \mathrm{p}=0.001$ ). Time effects were observed in all anthropometric measurements including waist and hip, as well as weight loss, fat mass and percent body fat. Subjects on the HP diet experienced greater reductions in weight than those on the $\mathrm{HC}$ diet $(\mathrm{HP}-3.1 \pm 3.4 \%$; $\mathrm{HC}$ $-2.3 \pm 2.5 \%, \mathrm{p}=0.005)$ and fat mass (HP $-1.7 \pm 3.1 \%$; HC $-1.3 \pm 2.0 \%, \mathrm{p}=0.006$ ). No differences were seen in any measures in subjects with $>$ mTG. However, a Time $x$ Diet $\mathrm{x}$ mTG interaction was observed in changes in hip circumference. Subjects in the HP diet with $<$ mTG experienced a greater reduction in hip circumference $(-2.7 \pm 4.8 \%)$ than those with $>$ mTG levels $(-2.4 \pm 4.8 \%$, $\mathrm{p}=0.029)$ while subjects in the $\mathrm{HC}$ diet with $>\mathrm{mTG}$ experienced a greater reduction in hip circumference $(-3.4 \pm 4.8 \%)$ than those with $<$ mTG levels $(-1.9 \pm 3.4 \%$, $\mathrm{p}=0.029)$.

Time effects were also observed in systolic and diastolic blood pressures, REE, cholesterol, high density 
lipoprotein (HDL), low density lipoprotein (LDL) and uric acid. While no time effects were observed with changes in TG, subjects on the HP diet experienced a significantly greater reduction $(\mathrm{p}=0.048)$ in TG levels $(-5.6 \pm 34.0 \%)$ than those on the $\mathrm{HC}(2.0 \pm 36.5 \%)$ while subjects with $>\mathrm{mTG}$, also experienced a greater reduction $(\mathrm{p}=0.02)$ in TG levels $(-12.3 \pm 29.8 \%)$ than those with $<$ mTG $(9.1 \pm 39.4 \%)$.

\section{Conclusion}

Results reveal that diet combined with circuit training promotes decreases in waist and hip circumference, weight loss, fat mass and body fat percentage while concomitantly reducing blood pressure, cholesterol and uric acid, and increasing resting energy expenditure. A HP diet promotes greater reductions in weight loss, fat mass and TG levels. Greater reductions in TG levels were experienced by individuals with mTG levels $>125 \mathrm{mg} /$ dL. While a HP diet promotes greater reductions in TG, individuals with TG levels $>125 \mathrm{mg} / \mathrm{dL}$ experience greater reductions regardless of diet.

\section{Acknowledgement}

We would like to thank Jean Jitomir, Monica Serra, Jen Moreillon, Erika Deike, Geoffrey Hudson, and Mike Greenwood who assisted in data collection on the first cohort of subjects that participated in this study when the ESNL was located at Baylor University. This study was supported by Curves International, Waco, TX.

\section{Author details}

'Exercise and Sports Nutrition Laboratory, Texas A \& M University, College Station, TX, USA . ${ }^{2}$ Applied Biochemistry and Molecular Physiology

Laboratory, University of Oklahoma, Norman, OK, USA.

Published: 15 September 2010

doi:10.1186/1550-2783-7-S1-P9

Cite this article as: Oliver et al:: Effects of high carbohydrate or high protein energy-restricted diets combined with resistance-exercise on weight loss and markers of health in women with serum triglyceride levels above or below median values. Journal of the International Society of Sports Nutrition 2010 7(Suppl 1):P9.
Submit your next manuscript to BioMed Central and take full advantage of:

- Convenient online submission

- Thorough peer review

- No space constraints or color figure charges

- Immediate publication on acceptance

- Inclusion in PubMed, CAS, Scopus and Google Scholar

- Research which is freely available for redistribution

Submit your manuscript at www.biomedcentral.com/submit 